\title{
Oxadiazon Residues in Surface Water and Crucian Carps (Carassius Cuvieri) of Lake Kojima
}

\author{
Masaaki Imanaka, Seiji Hino, Kazuyoshi Matsunaga and Tatsuo Ishida \\ Okayama Prefectural Research Center of Environment and Public Health, \\ Uchio, Okayama 701-02, Japan
}

(Received October 2, 1984)

\begin{abstract}
In order to study the fate of oxadiazon in the field, the residue level in river water and crucian carps was investigated in the area near Lake Kojima where a large amount of it was applied. The sampling period was from 1980 to 1982. All the year oxadiazon was detected in the surface water of Lake Kojima, the Sasagase and the Seno River. Moreover, it was also detected in crucian carps living in Lake Kojima. The level was several hundred times higher in the latter than the former. Time course of the level in crucian carps showed a very similar pattern to that in river water, which indicated that the residue level reflected directly the level of contamination of the water in which they live, almost without any time lag. The values of biological concentration factor were mostly in the range 200-400 irrespective of whether the level in fish is low or high. The degradation experiment in the model system showed that oxadiazon might be very stable in the environment. This result compared well with that in the field. Mass spectrometry and mass chromatography identified oxadiazon from the crucian carps (March 12, 1981) in which $0.017 \mathrm{ppm}$ was detected on ECD gaschromatogram.
\end{abstract}

\section{INTRODUCTION}

Oxadiazon, an oxadiazole herbicide, is used alone or together with other herbicides in the rice-planting season. ${ }^{1)}$ This is one of the most used herbicides in the basin of the Sasagase River and the Kurashiki River, a typical paddy field area in Okayama Prefecture, and is applied intensively within a short period.

The bulk of oxadiazon applied is adsorbed and retained on the soil during irrigation, ${ }^{2)}$ but the amount washed away into the river by draining is not negligible. Because the season when oxadiazon is used in the southern area of Okayama Prefecture almost coincides with the rainy season when it sometimes rains heavily, a large amount of herbicide is not seldom carried away together with the surface soil immediately after application. Therefore the impact on fish and shellfish cannot be neglected. Particularly if main rivers flow into a lake through the farming region, there is a worry about strong and persistent influence on the ecosystem because agricultural chemicals will be carried into and accumulated in the lake together with the soil.

From this point of view, the authors analyzed the oxadiazon residue in crucian carps (Carassius cuvieri) caught in Lake Kojima on August 13, 1980 and reported that a considerably high level of oxadiazon was found in the flesh and oxadiazon might have the possibility of being persistent in the fish. ${ }^{3)}$

In the present study, the analytical method (GC conditions) reported in the preceding paper was discussed in more detail, and the time course of the residue level of oxadiazon was followed in surface water of Lake Kojima, the Sasagase River and the Seno River and in crucian carps in Lake Kojima during the period from 1980 to 1982 . The correlation between its residue level in water and in 
crucian carps was discussed. In addition, degradation of oxadiazon and other herbicides was also investigated.

\section{MATERIALS AND METHODS}

\section{Sample}

\subsection{River and lake water}

One $l$ of surface water $(0-15 \mathrm{~cm})$ was obtained respectively at the sites of Lake Kojima, the Sasagase River and the Seno River (Fig. 1). 1.2 Fish

Crucian carps and carps (Cyprinus carpio) were caught at a central part of Lake Kojima. They were kept under $-20^{\circ} \mathrm{C}$.

\section{Reagent}

Oxadiazon, chlornitrofen (CNP), nitrofen (NIP), swep (MCC), benthiocarb and fenitrothion (MEP) were purchased from Wako Pure Chemical Industry (Osaka). All solvents were of pesticide analysis grade. Sodium Chloride $(\mathrm{NaCl})$ was of analytical grade and heated at $500^{\circ} \mathrm{C}$ overnight. Florisil was 60-100 mesh PR grade (Floridin Co., U.S.A.) and activated at $130^{\circ} \mathrm{C}$ overnight. $2 \% \mathrm{NaCl}$ solution was washed with small aliquots of $n$-hexane 2 times before use.

All stock solutions were prepared in benzene at $100 \mathrm{ppm}$ for calibration or in ethanol at $1000 \mathrm{ppm}$ for degradation experiment. Secondary dilution standards were prepared in $n$-hexane or ethanol.

The column packing, 2\% DEGS $+0.5 \%$ $\mathrm{H}_{3} \mathrm{PO}_{4}$ on $80-100$ mesh Gaschrom Q, was obtained from Wako Pure Chemical Industry.

\section{Gas Chromatography $(G C)$}

A Shimadzu GC-4BM equipped with ${ }^{63} \mathrm{Ni}$ ECD was used. A $2.0 \mathrm{~m} \times 2.6 \mathrm{~mm}$ i.d. glass column was packed with $2 \%$ DEGS $+0.5 \%$ $\mathrm{H}_{3} \mathrm{PO}_{4}$ on 80-100 mesh Gaschrom Q. Nitrogen $(60 \mathrm{ml} / \mathrm{min})$ was employed as a carrier gas. Operating conditions were as follows: injection port, $250^{\circ} \mathrm{C}$; oven, $190^{\circ} \mathrm{C}$; detector, $265^{\circ} \mathrm{C}$.

\section{Gas Chromatography-Mass Spectrometry $(G C-M S)$}

A Shimadzu LKB 9000 with MASPAC 90 was used. A $1.0 \mathrm{~m} \times 3.0 \mathrm{~mm}$ i.d. glass column was packed with $2 \%$ DEGS $+0.5 \% \mathrm{H}_{3} \mathrm{PO}_{4}$ on 80-100 mesh Gaschrom Q. Helium $(20 \mathrm{ml} /$

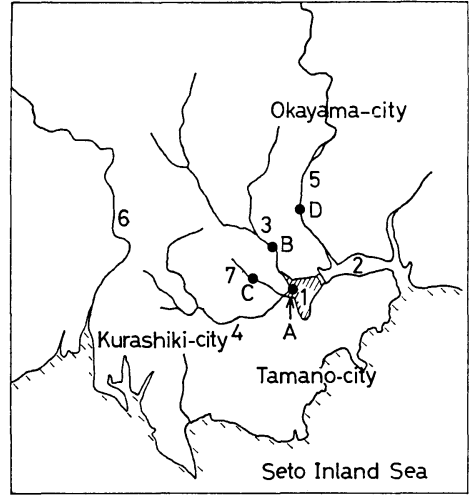

Fig. 1 Map showing Lake Kojima area of Okayama Prefecture, Japan.

" $\mathrm{A}$ " is the sampling site of Lake Kojima. " $\mathrm{B}$ " is the sampling site of the Sasagase River. " $\mathrm{C}$ " is the sampling site of the Seno River. " $D$ " is the sampling site of the Asahi River. 1: Lake Kojima, 2: Kojima Bay, 3: Sasagase River, 4: Kurashiki River, 5: Asahi River, 6: Takahashi River, 7: Seno River.

min) was employed as a carrier gas. Operating conditions were as follows: injection port, $240^{\circ} \mathrm{C}$; oven, $190^{\circ} \mathrm{C}$; separator, $270^{\circ} \mathrm{C}$; ion source, $290^{\circ} \mathrm{C}$; electron energy, $70 \mathrm{eV}$; accelerating voltage, $3.5 \mathrm{kV}$; trap current, 60 $\mu \mathrm{A}$; interval (mass chromatography), $10 \mathrm{sec}$.

\section{Preparation of Samples}

River water: One $l$ of river water was taken into $2 l$ separatory funnel, to which $50 \mathrm{ml}$ of dichloromethane was added, and shaken for $5 \mathrm{~min}$, and the lower phase was taken. If the separation was insufficient, the mixture was centrifuged. After two more cycles of extraction, all dichloromethane phases were combined, dehydrated with anhydrous sodium sulfate and subjected to evaporation of the solvent under reduced pressure at $30^{\circ} \mathrm{C}$. The residue was dissolved in about $5 \mathrm{ml}$ of $n$-hexane and cleaned up by Florisil column chromatography; i.e. $10 \mathrm{~g}$ of activated Florisil was packed in a $2 \mathrm{~cm}$ i.d. glass column as a slurry with $n$-hexane and $5 \mathrm{~g}$ of anhydrous sodium sulfate was put on the top. To this column the $n$-hexane solution described above was charged, and after flowing $150 \mathrm{ml}$ of $n$-hexane (Fraction 1), the fraction containing oxadiazon was 
eluted with $150 \mathrm{ml}$ of $30 \%$ diethyl ether in $n$ hexane (Fraction 2). The eluate was concentrated to an appropriate volume under reduced pressure at $30^{\circ} \mathrm{C}$ and injected into ECD-GC.

Fish and shellfish ${ }^{3)}$ : Edible flesh of fish (7 or 8 fish), after removing bones, skin, and internal organs was minced. Flesh of shellfish after removing shell was minced. Fifty $g$ of minced flesh was placed in a $300 \mathrm{ml}$ Erlenmeyer flask, dehydrated with $100 \mathrm{~g}$ of anhydrous sodium sulfate and extracted with $n$-hexane $(100 \mathrm{ml} \times 1,50 \mathrm{ml} \times 4)$ by homogenizing sufficiently with Polytron (Kinematica, Switzerland). After drying the combined $n$-hexane extracts, the solvent was evaporated completely under reduced pressure at $30^{\circ} \mathrm{C}$ to render fat, which was weighed and dissolved in $40 \mathrm{ml}$ of $n$ hexane, $20 \mathrm{ml}$ of which was further extracted with acetonitrile saturated with $n$-hexane $(30$ $\mathrm{ml} \times 3)$. The acetonitrile extract thus obtained $(90 \mathrm{ml})$ was washed with $10 \mathrm{ml}$ of $n$-hexane and after addition of $500 \mathrm{ml}$ of $2 \% \mathrm{NaCl}$, extracted with $n$-hexane $(100 \mathrm{ml} \times 2)$. The $n$ hexane phase was washed with $50 \mathrm{ml}$ of $2 \%$ $\mathrm{NaCl}$, dried, concentrated to about $5 \mathrm{ml}$ under reduced pressure at $30^{\circ} \mathrm{C}$ and charged on a Florisil column. Then the fractionation by column chromatography followed by analysis with ECD-GC was performed in the same way as for the sample of river water.

\section{Degradation Experiment}

A thermostat was placed at the window in the laboratory which was bright but not exposed to the direct rays of sun, and kept at $20 \pm 0.1^{\circ} \mathrm{C}$ with Coolnics Circulator (KomatsuYamato Co., Tokyo). Into a $300 \mathrm{ml}$ transparent glass-stoppered Erlenmeyer Flask, 300 $\mathrm{ml}$ of river water (the Asahi River surface water) was taken and pre-incubated for 3 days, to which oxadiazon (final concentration: 0.01 ppm), CNP (0.01 ppm), NIP (0.01 ppm), MEP (0.02 ppm), MCC (0.04 ppm) and benthiocarb $(0.10 \mathrm{ppm})$ were added with $0.3 \mathrm{ml}$ of ethanol. The flask was tightly stoppered and incubated at $20 \pm 0.1^{\circ} \mathrm{C}$ for 50 days. Then the whole content of the flask was transferred into a separatory funnel, to which $20 \mathrm{ml}$ of $2 \%$ $\mathrm{NaCl}$ solution was added and extracted with $n$ hexane $(100 \mathrm{ml} \times 1,50 \mathrm{ml} \times 2)$. The hexane extract was washed with water, dried, con- centrated to $10 \mathrm{ml}$ under reduced pressure at $30^{\circ} \mathrm{C}$ and injected into ECD-GC. Separately, $300 \mathrm{ml}$ of distilled water instead of the river water was subjected to the same degradation experiment, serving as the control. Both the river water and the control in open flasks were also incubated so that the change due to evaporation from aqueous solution might be also investigated.

\section{RESULTS AND DISCUSSION}

\section{Separation of Oxadiazon, Dieldrin and $M C C$ on ECD Gas Chromatography}

Analysis was performed according to the procedure described in the previous paper. ${ }^{3)}$ In the analysis of oxadiazon, attention should be paid to the behavior of dieldrin and MCC. Dieldrin, which is issued still now as a contaminant, because it is found in mother's milk has a retention time comparable to that of oxadiazon. However, the difference of the retention time between the two in a $2 \mathrm{~m} \mathrm{DEGC}+\mathrm{H}_{3} \mathrm{PO}_{4}$ column remains constant, dieldrin being eluted slightly later and thus the interference by dieldrin can be avoided (Fig. 7). On the other hand, the difference of retention time between MCC and oxadiazon may change along with time. On the glass column packed with $\mathrm{DEGS}+\mathrm{H}_{3} \mathrm{PO}_{4}$, the difference of retention time immediately after aging (Fig. 2, the difference between peak 2 and peak 3) decreases

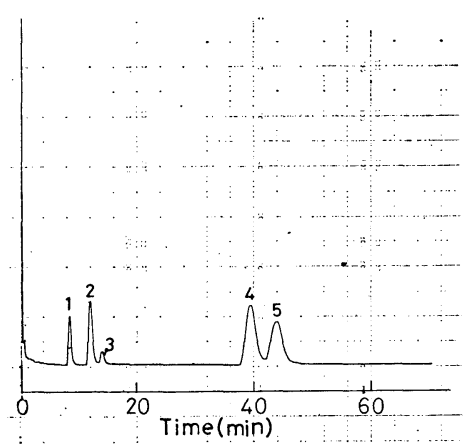

Fig. 2 Typical ECD gaschromatogram of herbicide standards.

1: benthiocarb, 2: oxadiazon, 3: swep (MCC), 4: nitrofen (NIP), 5: chlornitrofen (CNP). The separation of the peaks 2 and 3 , which is pretty good on the new GC column (as is Fig. 2), becomes poor gradually with the passage of time. 
gradually from 1 month after the attachment of the column to GC (the retention time of MCC becomes shorter), until both retention times become equal. Therefore the resolution of the peaks should be checked often when a column is used over a long time or when a column which has been used previously is to be used again.

\section{Oxadiazon in the Surface Water of Lake Kojima}

Lake Kojima is an artificial fresh-water lake which was made in 1959 (area: 1100 ha), the second-rate rivers (the Sasagase River and the Kurashiki River) flow through a farming region (Fig. 1). Therefore, it may easily be expected that herbicides, applied intensively late in June in the rainy season, may flow through the rivers into Lake Kojima and greatly influence the ecosystem. If the soil adsorbing the herbicides etc. is accumulated at the same time, the influence may persist long. From this point of view the oxadiazon level in the water of Lake Kojima has been investigated as an item of the water quality test since April in 1981 (The surface water, sampling site: Fig. 1).

Figure 3 is the ECD gaschromatogram of lake water collected on May 3, 1982 when the smallest influence of oxadiazon was expected (because the longest time had elapsed after application in June of the year before). Considerably many peaks appeared (concentration rate: $500 \mathrm{ml} \rightarrow 1 \mathrm{ml}$ ), among which the small

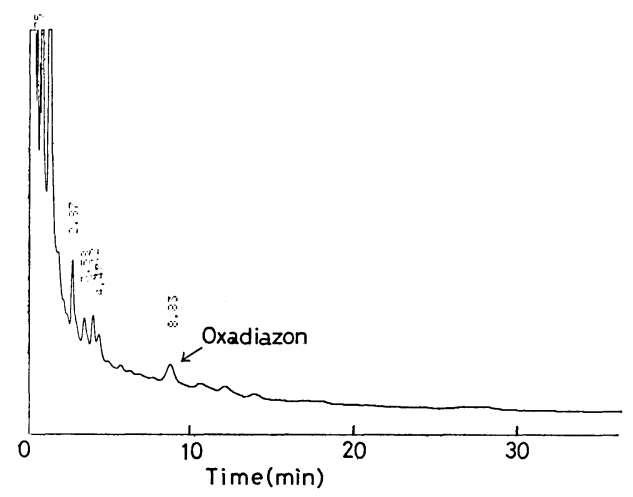

Fig. 3 ECD gaschromatogram of the $n$-hexane extract from Lake Kojima surface water $(500 \mathrm{ml})$ collected on May 5, 1982.

The injection volume is $1 \mu \mathrm{l} / 3 \mathrm{ml}$. peak due to oxadiazon was detected $(0.078$ $\mathrm{ppb})$; it was thus suggested that the lake water (surface water) was always contaminated at ppt level.

On the other hand, the ECD gaschromatogram represented by Fig. 4 (June 20, 1981) were obtained late in June when the greatest influence of herbicide application was expected; the chromatograms indicate the progressive contamination with oxadiazon. The change of oxadiazon residue level with time is summarized in Fig. 5. The oxadiazon level increased rapidly about June 14, 1981, reached a peak of about $6 \mathrm{ppb}$ and decreased first rapidly and then gradually (August-October) until it remained almost constant from November on. A similar pattern was also found in 1982.

Comparison of the level of contamination in 1981 with that in 1982 revealed that the level late in June 1982 was about one fourth of that in 1981. One reason for this may be the difference of rainfall in the season of herbicide application; in 1981 it rained often and heavily in the middle and the end of Junes) in the rice-planting season so that a large amount of herbicides were washed into the rivers, whereas in the same season in 1982 it scarcely rained at all so that the amount of herbicides washed there might have been smaller. In addition, factors such as difference of

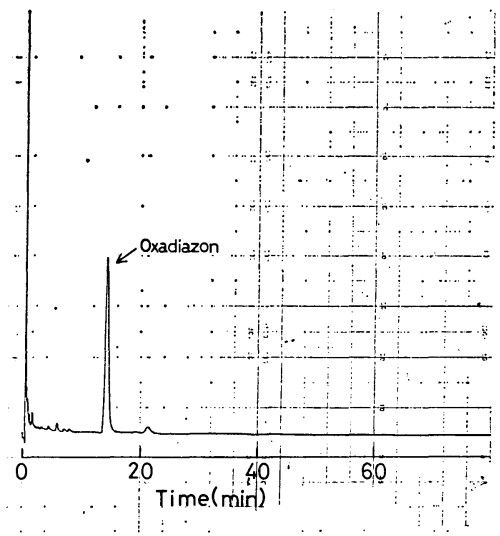

Fig. 4 ECD gaschromatogram of the $n$-hexane extract from Lake Kojima surface water $(500 \mathrm{ml})$ collected on June 20, 1981.

The injection volume is $1 \mu \mathrm{l} / 3 \mathrm{ml}$. 


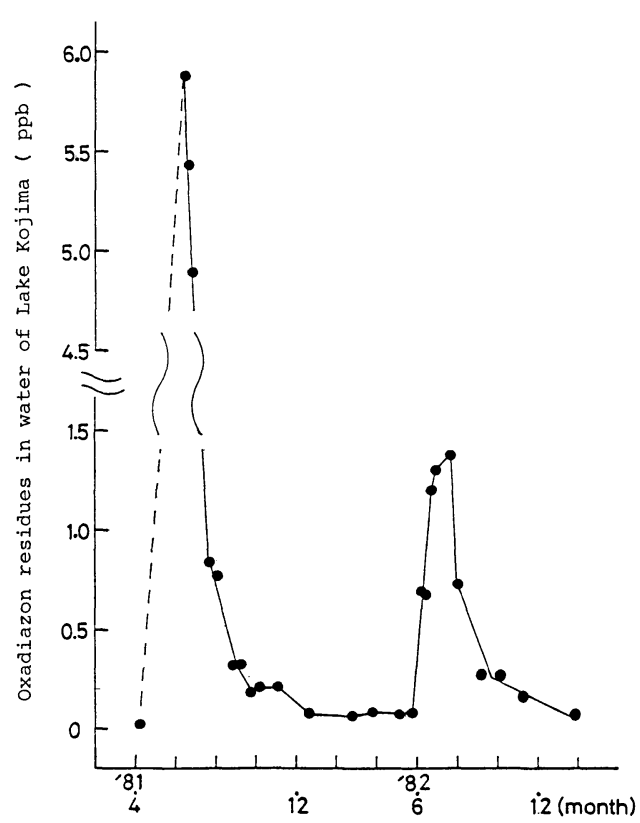

Fig. 5 Seasonal variability of Oxadiazon residue level in Lake Kojima surface water.

A dotted line shows that the data are lacking.

amount of oxadiazon applied and improvement of application method, ${ }^{5)}$ should also be taken into account. Further study is required to know the actual reasons for the change of level.

3. Change of the Level of Oxadiazon in the Sasagase River and the Seno River

The Sasagase River is one of the two largest rivers flowing into Lake Kojima (Fig. 1). The Seno River, though a smaller river, also flows into Lake Kojima, gathering much water directly from paddy fields and reflecting the influence of herbicide application. Therefore investigation of the actual residue level of oxadiazon may provide much information useful for clarification of causes and processes for contamination of Lake Kojima.

Figure 6 shows the change of residue level in the surface water of the Sasagase River (sampling site: Fig. 1) during the period from June 1980 to December 1982. The 3 sharp peaks correspond to the times of oxadiazon application. Each peak shows very similar changes to that of Lake Kojima. The change of the level in the Seno River is also similar

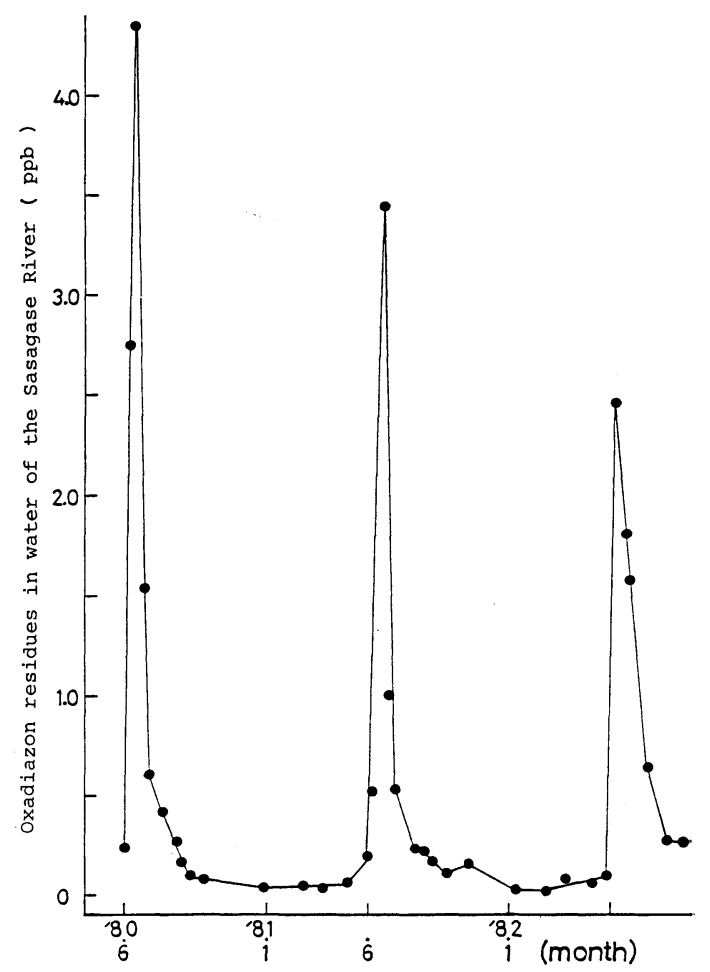

Fig. 6 Seasonal variability of Oxadiazon residue level in the Sasagase River surface water.

to that found in Figs. 5 and 6. The level in 1982 was considerably lower than that in 1981, which agrees with the results obtained in Lake Kojima.

Even in the river water samples collected in winter to spring at all of the 3 sites investigated, a trace amount $(<0.1 \mathrm{ppb})$ of oxadiazon was detected. The reason for this may be that oxadiazon adsorbed once on soil may be released gradually into river water because oxadiazon is strongly adsorbed on soil ${ }^{2)}$ and relatively stable there. ${ }^{6-8)}$

\section{Oxadiazon Residue Level in Crucian Carps Collected in Lake Kojima}

Contamination with various kinds of herbicides in fresh water fish, shellfish and shortnecked clams has been investigated in many places, and it has been reported that the herbicides may persist only transiently during and immediately after the time of application..$^{9-12)}$

The authors suggested in the previous paper ${ }^{3)}$ that oxadiazon may have a strong persistence 


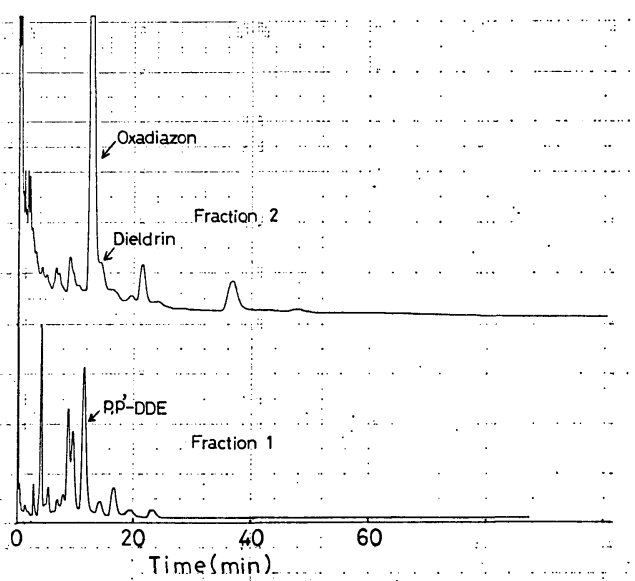

Fig. 7 ECD gaschromatograms of the $n$-hexane extract from crucian carps collected on July 12 , 1982.

Top: Second fraction on Florisil column chromatography. The injection volume is $1 \mu \mathrm{l} / 5 \mathrm{ml}$. Bottom: First fraction on Florisil column chromatography. The injection volume is $1 \mu \mathrm{l} / 4 \mathrm{ml}$.

in fish and shellfish because $0.017 \mathrm{ppm}$ of oxadiazon was detected in crucian carps (from Lake Kojima) caught about 9 months after the application of the herbicide. However, the level in the crucian carps may rather have reflected only the relatively high biological concentration because the herbicide was also detected in the lake water though at a low level $(0.024 \mathrm{ppb})$. In order to clarify this point at field level, crucian carps were caught at intervals and the residue level in them was followed. Figures 7 and 8 are ECD gaschromatograms of the crucian carps caught on July 12, 1982 and on March 12, 1982, respectively. Figure 9 shows the time course of the level.

Comparison of the concentration on the ordinate in Fig. 5 with those on Fig. 9 revealed that the biological concentration by several hundred times is clearly recognized in the latter figure, though the residue levels changed in very similar patterns to each other, showing the residue level in crucian carps reflects directly the level of contamination of the water where they live (almost without any time lag). Especially when the level in the fish was high $(>0.5 \mathrm{ppm})$, the level in the fish decreased

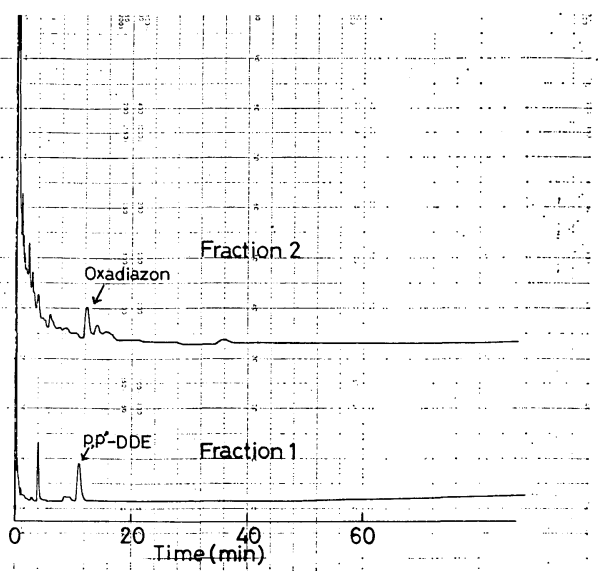

Fig. 8 ECD gaschromatograms of the $n$-hexane extract from crucian carps collected on March 12, 1981.

Top: Second fraction on Florisil column chromatography. The injection volume is $1 \mu \mathrm{l} / 5 \mathrm{ml}$. Bottom: First fraction on Florisil column chromatography. The injection volume is $1 \mu 1 / 4 \mathrm{ml}$.

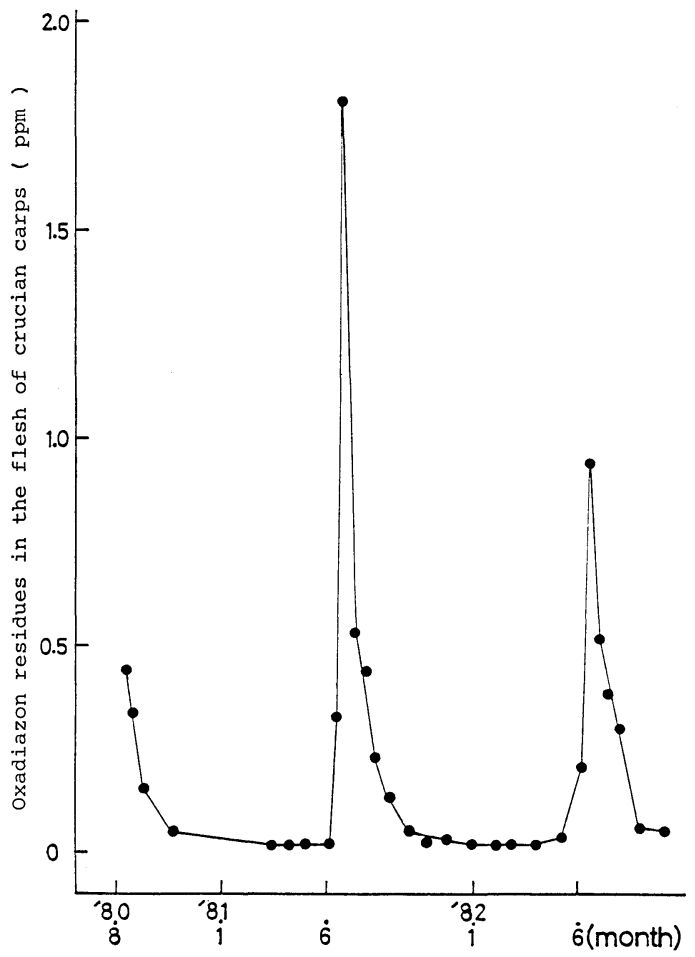

Fig. 9 Seasonal variability of oxadiazon residue level in crucian carps collected in Lake Kojima. Each point shows the value obtained from the mixture of seven samples. 


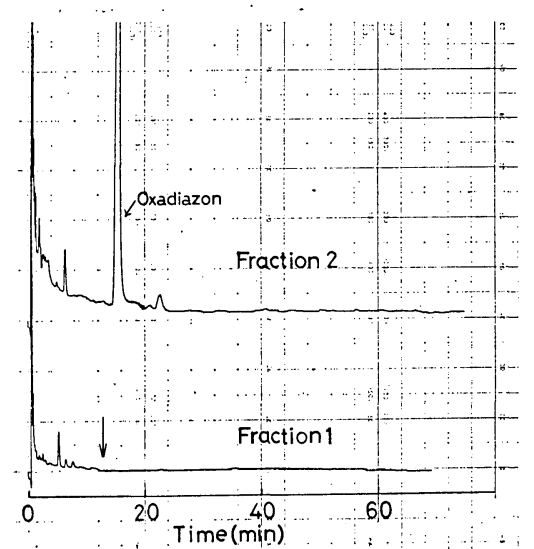

Fig. 10 ECD gaschromatograms of the $n$ hexane extract from the Seno River surface water (500 ml) collected on June 17, 1981.

Top: Second fraction on Florisil column chromatography. The injection volume is $1 \mu 1 / 1 \mathrm{ml}$. Bottom: First fraction on Florisil column chromatography. The injection volume is $1 \mu 1 / 2 \mathrm{ml}$. Arrow ( $\downarrow$ ) shows the Retention Time of $p, p^{\prime}-$ DDE.

rapidly along with the decrease of the level in the river water; this suggests that, at least at higher levels, the persistence may be not very strong.

Figure 10 is the ECD gaschromatograms (Fraction 1 and 2) of the surface water collected from the Seno River on June 17, 1981. This is a typical ECD gaschromatograms of the river water collected from the surrounding rivers of Lake Kojima during the time of oxadiazon application. Though $p, p^{\prime}-$ $\mathrm{DDE}$ is clearly detected in the crucian carps caught during this time (0.025 ppm: Fig. 8), the peak due to this compound cannot be found in the river water concentrated at this rate $(500 \mathrm{ml} \rightarrow 1 \mathrm{ml})$. This supports the fact that the persistence of $p, p^{\prime}-\mathrm{DDE}$ in the fish is very strong (i.e. biological concentration is very strong). In fresh water where crucian carps containing oxadiazon at the same level as p.p'-DDE (e.g. $0.023 \mathrm{ppm}$ on March 30, 1982) live, a very low level of herbicide is always found (e.g. $0.089 \mathrm{ppb}$ on March 22, 1982). This fact suggests that the low level of oxadiazon in crucian carps caught in winter to spring long after the time of application is not due to persistence of the herbicide accumulated during summer, but in equilibrium with the level in the winter at that time. Table 1 is the biological concentration factor $(\mathrm{BCF})$ calculated for clarification of the mechanism of oxadiazon accumulation in summer (at high level) and in winter (at low level) in the field. BCF values were calculated by the following equation.

$$
\mathrm{BCF}=C_{\mathrm{f}} / C_{\mathrm{w}}
$$

where $C_{\mathrm{f}}$ : concentration in fish $(\mathrm{ppb}), C_{\mathrm{w}}$ : concentration in river water $(\mathrm{ppb})$

For the crucian carps caught on June 14 and on June 20, 1981, the concentration and BCF values were determined individually. According to Table $1, \mathrm{BCF}$ values are almost constant irrespective of whether the level in fish is low $(<0.1 \mathrm{ppm})$ or high $(>0.1 \mathrm{ppm})$, which suggests the similarity of the mechanism of biological concentration. All of the crucian carps caught on June 14 showed low BCF values. The level of oxadiazon in the water may have been at the stage immediately after or on the way to increase and may not have reached an equilibrium yet. $\left(C_{\mathrm{w}}\right.$ used was the value on June 15, $5.88 \mathrm{ppb}$.)

These $\mathrm{BCF}$ values in Table 1 compare pretty well with those which Ambrosi et al. ${ }^{13)}$ determined in an aquatic model ecosystem. But for clarification of the mechanism of biological concentration in this report, the food-chain should also be taken into account. This is to be studied in future.

\section{Identification of Oxadiazon by Gas Chro- matography-Mass Spectrometry (GC-MS)}

In the previous paper, ${ }^{3)}$ oxadiazon was identified by GC-MS in the sample from crucian carps caught on August 13, 1980. In the present study identification was tried in crucian carps (March 12, 1981) which contained only $0.017 \mathrm{ppm}$ of oxadiazon determined by ECDGC: according to Materials and Methods 5. (fish and shellfish), the sample solution was prepared and the $n$-hexane solution used for determination with ECD-GC was charged again on the Florisil column to give Fraction 1 (150 $\mathrm{ml}$ of $n$-hexane), Fraction $2(150 \mathrm{ml}$ of $n$ hexane containing $15 \%$ diethyl ether) and the third fraction (Fraction 3) which contains the peak corresponding to oxadiazon with $150 \mathrm{ml}$ 
Table 1 Oxadiazon residue levels in crucian carps \& carps collected in Lake Kojima and biological concentration factor $(\mathrm{BCF})$ in the field.

\begin{tabular}{|c|c|c|c|c|c|c|c|}
\hline \multirow{2}{*}{\multicolumn{2}{|c|}{ Sample name }} & \multirow{8}{*}{$\begin{array}{l}\text { Sampling day } \\
\text { ' } 81,6,14\end{array}$} & \multicolumn{2}{|c|}{ Sample } & \multirow{2}{*}{$\begin{array}{c}\text { Fat } \\
\text { content } \\
(\%)\end{array}$} & \multicolumn{2}{|c|}{ Whole } \\
\hline & & & $\begin{array}{l}\text { Length } \\
\text { (cm) }\end{array}$ & $\begin{array}{l}\text { Weight } \\
\text { (g) }\end{array}$ & & $\begin{array}{l}\text { Basis } \\
(\mathrm{ppm})\end{array}$ & $\mathrm{BCF}$ \\
\hline \multirow[t]{6}{*}{ Crucian carp } & 1 & & 16.0 & 110 & 0.0345 & 0.435 & 73.9 \\
\hline & 2 & & 15.0 & 100 & 0.267 & 0.262 & 44.6 \\
\hline & 3 & & 16.5 & 150 & 0.464 & 0.632 & 108 \\
\hline & 4 & & 16.5 & 110 & 0.0729 & 0.124 & 21.1 \\
\hline & 5 & & 15.5 & 120 & 0.685 & 0.416 & 60.7 \\
\hline & 6 & & 15.0 & 100 & 0.132 & 0.359 & 61.1 \\
\hline \multirow[t]{2}{*}{ carp } & 1 & '81,6,14 & 47.5 & 2400 & 6.78 & 1.15 & 195 \\
\hline & 2 & & 47.5 & 2400 & 5.25 & 1.37 & 234 \\
\hline \multicolumn{3}{|c|}{ carp (egg) } & & & 17.2 & 2.71 & 461 \\
\hline \multirow[t]{6}{*}{ Crucian carp } & 1 & ' $81,6,20$ & 16.5 & 130 & 4.93 & 0.256 & 46.1 \\
\hline & 2 & & 16.5 & 160 & 2.60 & 5.02 & 905 \\
\hline & 3 & & 16.0 & 140 & 2.69 & 1.01 & 182 \\
\hline & 4 & & 15.5 & 140 & 4.68 & 1.77 & 319 \\
\hline & 5 & & 14.5 & 110 & 0.815 & 1.13 & 203 \\
\hline & 6 & & 18.5 & 160 & 1.29 & 1.65 & 298 \\
\hline \multirow[t]{2}{*}{ carp } & 1 & '81,6,20 & 39.0 & 1050 & 2.31 & 3.56 & 641 \\
\hline & 2 & & 32.0 & 850 & 1.98 & 2.04 & 368 \\
\hline \multirow{11}{*}{\multicolumn{2}{|c|}{ Crucian carps* }} & ' $81,11,22$ & $14.0-15.9$ & $98-121$ & 0.699 & 0.030 & 375 \\
\hline & & $' 82,2,23$ & $16.5-19.0$ & $124-216$ & 0.923 & 0.021 & 328 \\
\hline & & ' $82,3,30$ & $18.0-19.0$ & $172-212$ & 2.60 & 0.023 & 285 \\
\hline & & $' 82,5,9$ & $15.7-17.7$ & $146-172$ & 2.89 & 0.038 & 487 \\
\hline & & '82,6,6 & $15.5-18.8$ & $125-171$ & 0.681 & 0.208 & 303 \\
\hline & & $' 82,6,15$ & $21.0-24.0$ & $170-240$ & 2.06 & 0.942 & 788 \\
\hline & & $' 82,6,29$ & $20.0-21.5$ & $160-170$ & 1.36 & 0.518 & 398 \\
\hline & & ' $82,7,12$ & $23.0-26.0$ & $200-310$ & 2.18 & 0.386 & 280 \\
\hline & & $' 82,8,1$ & $19.5-22.0$ & $150-170$ & 1.69 & 0.304 & 416 \\
\hline & & ' $82,8,30$ & $20.0-24.0$ & $150-220$ & 0.569 & 0.063 & 199 \\
\hline & & $' 82,10,6$ & $20.0-23.5$ & $140-180$ & 0.594 & 0.055 & 263 \\
\hline
\end{tabular}

* Seven crucian carps were mixed.

of $n$-hexane containing $30 \%$ diethyl ether. This clean-up process may exclude almost completely the compounds interferring with the identification of a trace amount of oxadiazon (most of the interfering compounds are eluted in Fraction 2). When a large amount is charged onto the Florisil column (e.g. as in the first fractionation), a considerable amount of oxadiazon was eluted in the second fraction but in the refractionation all oxadiazon was eluted only in Fraction 3.

Figure 11 is the EI mass spectrum of Fraction 3, which is consistent with the standard compound, and thus it was identified to be oxadiazon. Peaks at $m / z=381,371,366,353$ and 322 found in the region with higher mass than that of parent peaks of oxadiazon $(m / z=344,346,348)$ were confirmed not to be characteristic to be the mass spectrum at the retention time of $5.8 \mathrm{~min}$ (Fig. 12).

\section{Degradation of Oxadiazon in River Water}

Though the region is limited only to the surrounding area of Lake Kojima, the detection of oxadiazon both in the river water and in crucian carps living in that region suggests the relatively low degree of degradation in the environment. In order to discover the stability in the environment, the authors investigated the change of the concentration when samples 

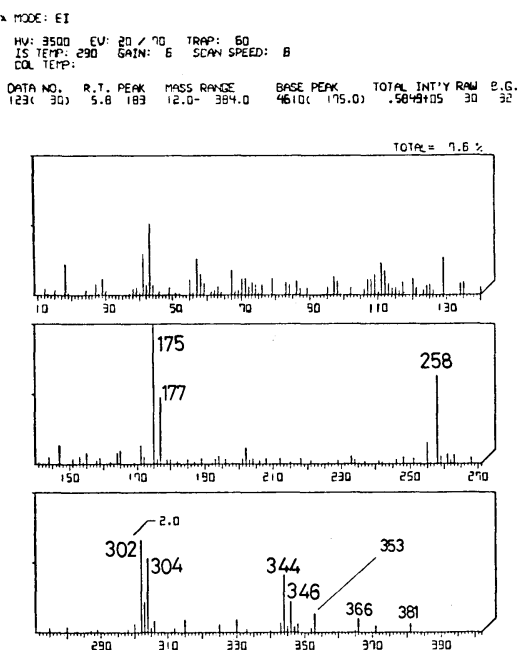

Fig. 11 EI mass spectrum of the peak corresponding to oxadiazon in the $n$-hexane extract from crucian carps collected on March 12, 1981.

See the text for the sample preparation. GC-MS conditions are listed in Materials and Methods 4.

were kept for a long time: the water of Lake Kojima collected on June 20, 1980 was placed in a glass bottle, which was then stoppered closely (shielded from light, at $4^{\circ} \mathrm{C}$ for 20 days). The concentration of oxadiazon determined before and after the incubation were $5.55 \mathrm{ppb}$ and $5.75 \mathrm{ppb}$, respectively, no degradation being detected.

Figure 13 is the comparison of ECD gaschromatograms at the start and at the end of the incubation in the surface water of the Asahi River (collected on June 6, 1981, pH 7.0,

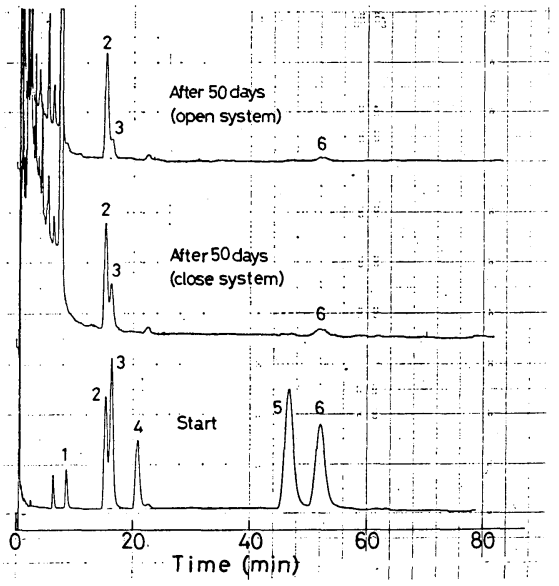

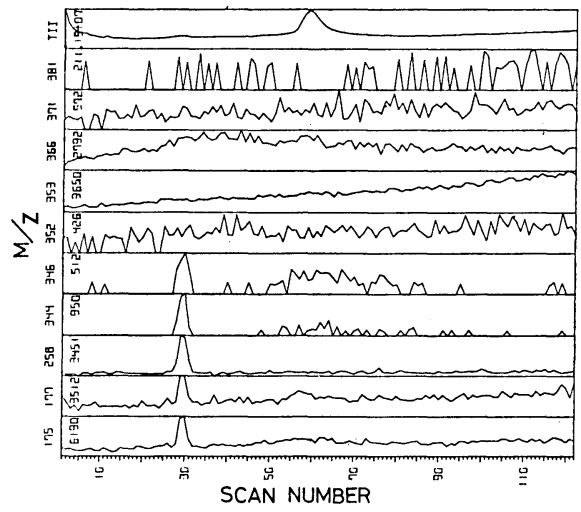

Fig. 12 Mass chromatogram of the $n$-hexane extract from crucian carps collected on March 12, 1981.

See Materials and Methods 4. for the GC-MS conditions.

water temperature: $21.0^{\circ} \mathrm{C}$ ) for 50 days in the laboratory according to Materials and Methods 6 . As the control, distilled water was used.

Generally in such degradation experiments the result may vary considerably according to the nature of the river water employed ${ }^{14,15)}$; however, as far as Table 2 shows, oxadiazon is very stable as compared with other herbicides and organophosphate (MEP).

As described above, oxadiazon may be detected in fish (crucian carps) and lake water all the year not only because of the geographical

Fig. 13 Degradation of five kinds of herbicides and fenitrothion (MEP) in the Asahi River surface water (obtained at the site " $D$ " of Fig. 1) at $20^{\circ} \mathrm{C}$.

See Materials and Methods 6. for the experimental method. 1: benthiocarb, 2: oxadiazon, 3: swep (MCC), 4: fenitrothion (MEP), 5: nitrofen (NIP), 6: chlornitrofen (CNP). 
Table 2 Degradation of five kinds of herbicides and fenitrothion (MEP) in the Asahi River surface water at $10^{\circ} \mathrm{C}$.

\begin{tabular}{lcccccccc}
\hline & \multirow{2}{*}{$\begin{array}{c}\text { Exp. } \\
\text { system }\end{array}$} & \multicolumn{6}{c}{ Pesticides (remaining ratio: \%) } \\
\cline { 3 - 8 } River & Open & Benthiocarb & Oxadiazon & MCC & MEP & NIP & CNP \\
\cline { 2 - 9 } Water & Closed & 8.6 & 93 & 1.3 & 0 & 0.96 & 4.6 \\
\hline Distilled & Open & 0 & 92 & 31 & 0 & 0.96 & 8.2 \\
\hline \multirow{2}{*}{ Water } & Closed & 100 & 100 & 44 & 58 & 98 & 100 \\
\hline
\end{tabular}

See Materials and Methods 6 . for the experimental method.

Benthiocarb (final concentration: $0.10 \mathrm{ppm}$ ), oxadiazon $(0.01 \mathrm{ppm}), \mathrm{MCC}(0.04 \mathrm{ppm}), \operatorname{MEP}(0.02$ ppm), NIP $(0.01 \mathrm{ppm})$ and $\mathrm{CNP}(0.01 \mathrm{ppm})$ were added to the Asahi River surface water or distilled water with $0.3 \mathrm{ml}$ of ethanol.

Results are the average of two trials.

characteristic of Lake Kojima, but also because of the relatively high stability on soil and of the resistence to degradation in river water.

\section{REFERENCES}

1) Okayama-ken Norinbu: "Application Methods of Herbicides," Okayama-ken Shokubutsu Boeki Kyokai, p. 2, 1982 (in Japanese)

2) D. Ambrosi \& J. Desmoras: Symposium Herbicides-Soils, Proceedings of the European Weed Research Council, p. 163, 1973

3) M. Imanaka, K. Matsunaga, A. Shigeta \& T. Ishida: J. Pesticide Sci. 6, 413 (1981)

4) H. Kato: Kisho 26, 12 (1982) (in Japanese)

5) Showa Rhodia Chemicals Co., Ltd.: Ronfriend (Pamphalet) (in Japanese)

6) D. Ambrosi, P. C. Kearney \& J. A. Macchia: J. Agric. Food Chem. 25, 868 (1977)

7) H. Hirata: "Methods in Pesticide Science," ed. by J. Fukami, Y. Uesugi, K. Ishizuka \& C. Tomizawa, Vol. 4, Soft Science Inc., Tokyo, p. 481, 1981 (in Japanese)

8) T. Ohya, T. Numata, T. Shinozaki \& J. Takano: Noyaku Seisan Gijyutsu 28, 26 (1972) (in Japanese)

9) Y. Hashimoto: J. Pesticide Sci. 7, 281 (1982)

10) K. Ishikawa, S. Suzuki, N. Sato, K. Takasugi \& K. Sakai: J. Food Hyg. Soc. 22, 56 (1981) (in Japanese)

11) T. Yamagishi, K. Akiyama, S. Kaneko, S. Horii, T. Miyazaki \& M. Morita: Annu. Rep. Tokyo Metrop. Res. Lab. Public Health 30, 123 (1979) (in Japanese)

12) S. Watanabe, S. Watanabe \& K. Ito: J. Pesticide Sci. 8, 47 (1983)
13) D. Ambrosi, A. R. Isensee \& J. A. Macchia: J. Agric. Food Chem. 26, 50 (1978)

14) P. H. Howard \& P. G. Deo: Bull. Environ. Contam. Toxicol. 22, 337 (1979)

15) A. Rosenberg: Bull. Environ. Contam. Toxicol. 32, 383 (1984)

\section{要約}

\section{除草剤オキサジアゾンの児島湖の湖水およびフ ナにおける挙動}

今中雅章，日野誠二，松永和義，石田立夫

除草剂オキサジアゾンの環境中での挙動を解明するた めに，その使用量が多い児島湖周辺地域（岡山市）を対 象として，河川水およびそこに生息するフナを 1980 82年にかけて継続してサンプリングし, 残留実態調査を 行なった．児島湖，笹ケ瀬川掞よび妹尾川の表層水とも に，つねにオキサジアゾンが検出され（児島湖：0.24〜

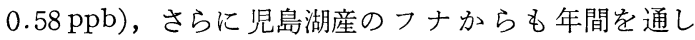
0.017 5.02 ppm の範囲で検出された. その濃度は, 後 者においてはるかに高く，ほぼ 200〜400 倍の生物濃縮 性が観察された。しかし，経時变化のパターンは両者と もによく類似しており, フナも，生息する水質の污染程 度を直接に反映していることが明らかになった。一方， 河川水を用いた室内分解実験の結果から，オキサジアゾ ソは非常に安定で, クロルニトロフェン (CNP) やフェ ニトロチオン (MEP) よりも難分解性であることが示唆 され,フィールドレベルでの調査結果を裏づけた。また, ECD.GC で非常に低いレベル (0.017 ppm) のオキサジ アゾンを検出したフナ $(1981 / 3 / 12)$ を用いて, EI マスス ペクトルによりその同定を行なった。 